\title{
Effect of silicon and potassium on tomato anthracnose and on the postharvest quality of tomato fruit (Lycopersicon esculentum Mill.)
}

\author{
Darshani Weerahewa* and Dilshan David \\ Department of Botany, Faculty of Natural Sciences, The Open University of Sri Lanka, Nawala, Nugegoda.
}

Revised: 13 February 2015; Accepted: 22 April 2015

\begin{abstract}
The resistance against anthracnose was investigated in tomato cutivars 'Thilina' and 'Maheshi' by soil application of silicon (Si) at 0 (control), 50 and $100 \mathrm{mg} / \mathrm{L}$ during the growth stage, flowering stage and both growth and flowering stages. It showed a reduction of lesions by $80 \%$ in 'Maheshi' and $87 \%$ in 'Thilina', respectively compared to the control irrespective of the cultivar and stage of the plant at which the treatment was given. Application of potassium (K) at twice (X2) and thrice (X3) the recommended dose to the plants reduced lesion size by over $30 \%$ or $85 \%$ in 'Thilina' and 'Maheshi' cultivars, respectively. In 'Maheshi, Si applied at 50 and $100 \mathrm{mg} / \mathrm{L}$ at all stages showed a significantly higher $(\mathrm{p} \leq 0.05)$ fruit size compared to the control. Plants treated with higher doses ( $\mathrm{x} 2$ and $\times 3$ ) of $\mathrm{K}$ also showed significantly higher fruit sizes compared to the control. Fruit firmness significantly increased in 'Maheshi' treated with 50 and $100 \mathrm{mg} / \mathrm{L} \mathrm{Si}$ applied at the growth or flowering stage. A significantly lower percentage of total acidity (TA \%) was observed in 'Thilina' treated with 50 or $100 \mathrm{mg} / \mathrm{L} \mathrm{Si}$ irrespective of the stage of plant. 'Thilina' treated with $\times 2$ or $\times 3$ doses of $\mathrm{K}$ showed significantly higher ( $\mathrm{p}$ $\leq 0.05$ ) total soluble solid (TSS). Also, the percentage number of appressoria formed (number of spores with appressoria/total number of spores $\times 100$ ) on areas inoculated with the fungus were significantly higher in fruits treated with $\times 3 \mathrm{~K}$ dose and all Si treated fruits compared to the control.
\end{abstract}

Keywords: Anthracnose, disease resistance, Maheshi, potassium, silicon, Thilina.

\section{INTRODUCTION}

Tomato (Lycopersicon esculentum Mill.) is a fruit vegetable in high demand and is susceptible to diseases and mechanical injuries during postharvest phases of the handling chain. In Sri Lanka, postharvest loss of tomato has been estimated to be in the range of $30-40 \%$ of the total production (Department of Agriculture, 2011).
Anthracnose is one of the major diseases of tomato, causing heavy postharvest loss of produce both in quality and quantity. This disease is controlled predominantly through the application of chemicals despite health and environmental concerns.

The current demand for sustainable crop production has increased the interest on non chemical control of pests and diseases. Numerous studies have shown that silicon (Si) is effective in controlling several fungal diseases in plants. Si increases the resistance in rice against leaf and neck blast, sheath blight, brown spot, leaf scald and stem rot (Rodrigues \& Datnoff, 2005). Among dicots, many records are available on the reduction of powdery mildew disease in cucumber, melon, zucchini squash (Menzies et al., 1992) and strawberry (Palmer, 2006). The significant control of many other diseases including phytophthora rot, molds disease, bacteria wilt, anthracnose, fusarium wilt and blight and leaf spot have also been recorded. Si could therefore be used as a non hazardous stratergy for disease control, as an alternative to fungicides to reduce the potential environmental threat to land and water.

The application of thrice the recommended dose of potassium $(\mathrm{K})$ has significantly reduced stem-end rot in mango variety 'Karuthacolomban' by over $45 \%$ compared to the recommended rate (Karunanayake, 2008). In banana, soil application of twice the recommended dose of $\mathrm{K}$ significantly reduced anthracnose, stalk-end rot and freckle infection in 'Embul' (Weerakoon et al., 2005). It has been reported that increasing the $\mathrm{K}$ fertilisation has reduced the incidence of stem-end rot and green mold of citrus, and consequently reduced fruit loss during transport and increased shelf life in the supermarket 
(Koo, 1985). In many horticultural crops, adequate K nutrition also contributed to increased yields, fruit size, soluble solids, ascorbic acid concentrations and shelf life and also improved fruit colour and shipping quality (Kanai et al., 2007).

This paper describes the potential of abiotic defence elicitor, $\mathrm{Si}$ and extra doses of $\mathrm{K}$ on improving the resistance to anthracnose of tomato cultivars 'Maheshi' and 'Thilina'. Some fruit quality traits of both $\mathrm{Si}$ and $\mathrm{K}$ treated fruits were also tested.

\section{METHODS AND MATERIALS}

\section{Experimental site}

Field experiments were conducted in farmers' fields of Doluwa village in the Kandy District (Central Province of Sri Lanka) during Maha 2011/2012 and Yala 2012 seasons. Doluwa is situated in the mid country Wet Zone of Sri Lanka with an elevation of $450-1200 \mathrm{~m}$ where the annual rainfall ranges between $1700-2250 \mathrm{~mm}$, and the average annual temperature is $28^{\circ} \mathrm{C}$. This site contains reddish brown latasolic soil.

\section{Tomato cultivars}

The department of Agriculture (DOA) recommended seeds of the two cultivars 'Maheshi' and 'Thilina' were used in the experiment. Seeds were dusted with fungicide (1\% Captan) $\left(\mathrm{C}_{9} \mathrm{H}_{8} \mathrm{Cl}_{3} \mathrm{NO}_{2} \mathrm{~S}\right)$ and sown in nursery beds consisting of compost, sand and top soil at a ratio of $1: 1: 1$.

\section{Preparation of beds and fertiliser application}

Plant beds $\left(3^{\prime} \times 4^{\prime}\right)$ were prepared with 12 planting holes per plant bed with a spacing of $50 \mathrm{~cm}$ between rows and $30 \mathrm{~cm}$ within rows. A basal fertiliser application consisting of $2.6 \mathrm{~g}$ of urea, $13.5 \mathrm{~g}$ of triple super phosphate (TSP) and $2.6 \mathrm{~g}$ of murate of potash (MOP) was added to each planting hole $4 \mathrm{~d}$ prior to transplanting. Two-week old, healthy tomato seedlings were selected and two seedlings were transplanted in each hole. $2.6 \mathrm{~g}$ of urea was added to each plant at 3 wks and 6 wks after transplanting. Three different concentrations of $\mathrm{K}$ using varied amounts of the potassium fertiliser, MOP $(2.8 \mathrm{~g}$ - recommended amount, $5.6 \mathrm{~g}$ - recommended amount $\mathrm{x} 2$ times and $8.4 \mathrm{~g}-$ recommended amount $\times 3$ times) were added after 6 wks of transplanting (Table I).

Table 1: Levels and application procedures of MOP and sodium silicate in different treatments

\begin{tabular}{|c|c|c|c|}
\hline No & Treatment & Level of application & Fertiliser application procedure \\
\hline 1 & Potassium & $\begin{array}{l}2.6 \text { g MOP-control } \\
\text { (DOA recommendation) }\end{array}$ & $\begin{array}{l}\text { Started } 6 \text { weeks after transplanting } \\
\text { ( } 2.6 \mathrm{~g} \text { MOP added as the basal application) }\end{array}$ \\
\hline 2 & Potassium & $\begin{array}{l}5.2 \mathrm{~g} \text { MOP } \\
\text { (twice the DOA recommendation) }\end{array}$ & $\begin{array}{l}\text { Started } 6 \text { weeks after transplanting } \\
\text { ( } 2.6 \mathrm{~g} \text { MOP added as the basal application) }\end{array}$ \\
\hline 3 & Potassium & $\begin{array}{l}7.8 \mathrm{~g} \text { MOP } \\
\text { (thrice the DOA recommendation) }\end{array}$ & $\begin{array}{l}\text { Started } 6 \text { weeks after transplanting } \\
\text { ( } 2.6 \mathrm{~g} \text { MOP added as the basal application) }\end{array}$ \\
\hline 4 & Silicon & $\begin{array}{l}50 \mathrm{mg} / \mathrm{L} \text { sodium silicate } \\
\text { (Sigma Aldrich Inc., USA) }\end{array}$ & $\begin{array}{l}\text { Started } 2 \text { weeks after planting and } \\
\text { continued until the flowering stage at } \\
\text { 2-week intervals }\end{array}$ \\
\hline 5 & Silicon & $50 \mathrm{mg} / \mathrm{L}$ sodium silicate & $\begin{array}{l}\text { Started at flowering stage and continued } \\
\text { at 2-week intervals }\end{array}$ \\
\hline 6 & Silicon & $50 \mathrm{mg} / \mathrm{L}$ sodium silicate & $\begin{array}{l}\text { Started } 2 \text { weeks after planting and } \\
\text { continued up to harvesting at } 2 \text {-week intervals }\end{array}$ \\
\hline 7 & Silicon & $100 \mathrm{mg} / \mathrm{L}$ sodium silicate & $\begin{array}{l}\text { Started } 2 \text { weeks after planting and continued until } \\
\text { the flowering stage at } 2 \text {-week intervals }\end{array}$ \\
\hline 8 & Silicon & $100 \mathrm{mg} / \mathrm{L}$ sodium silicate & $\begin{array}{l}\text { Started at flowering stage and continued } \\
\text { at } 2 \text {-week intervals }\end{array}$ \\
\hline 9 & Silicon & $100 \mathrm{mg} / \mathrm{L}$ sodium silicate & $\begin{array}{l}\text { Started } 2 \text { weeks after planting and continued } \\
\text { up to harvesting at } 2 \text {-week intervals }\end{array}$ \\
\hline
\end{tabular}




\section{Si application}

Water soluble silicon in the form of sodium silicate (Sigma Aldrich Inc., USA) was dissolved in normal water to make two concentrations of the silicon solution (50 and $100 \mathrm{mg} / \mathrm{L}$ ) and applied to each tomato seedling at different growth stages of the seedling (Table 1).

\section{Treatments and experimental design}

Two separate experiments were conducted with each cultivar. Nine treatments consisting of 3 levels of $\mathrm{K}$ and 2 levels of Si with 3 stages of application were arranged in a completely randomized design (CRD) with 2 replicates.

\section{Determination of physical and physicochemical parameters of fruits}

Thirty six tomato fruits ( 3 fruits per plant) representing each treatment as per Table 1, which were at colour break stage were used to measure the parameters mentioned below. Weight of the fruit was measured using an electronic balance (Model PW 184, aeADAM, China). Size of the fruit (diameter) was measured at the widest point using a measuring tape. Firmness of the fruit was measured using a penetrometer (Model FT 40, Wagner Instruments, Greenwich CT).

\section{Total soluble solids (TSS)}

Tomato fruit extract was obtained by crushing the fruits separately using a blender and squeezing the pulp through a muslin cloth. A drop of tomato extract was placed on the hand-held refractometer [Model, WZ-113, China (Mainland)] within the range of $0-32 \%$ Brix and the TSS value was taken.

\section{Acidity}

The tomato extract obtained for the above experiment was also used to determine the acidity. Aliquots $(2 \mathrm{~mL})$ of tomato extract were titrated against $0.1 \mathrm{M} \mathrm{NaOH}$ in triplicate, with phenolphthalein as an indicator. Titratable acidity ( $\%$ TA) for each sample was determined according to the method described by Askar and Trepow (1993).

\section{Preparation of fungal cultures}

Colletotrichum gloeosporioides was isolated from an anthracnose lesion of a ripened tomato fruit and identified using the Commonwealth Mycological Institute (CMI) description. The fungus was maintained on potato dextrose agar (PDA) at $28 \pm 2{ }^{\circ} \mathrm{C}$. The pathogenicity of the isolates was maintained by inoculation of tomato fruit and re-isolation at 2 month intervals.

A suspension of conidia of each fungus was prepared by scraping the mycelium from 14-day old pure cultures and suspending in sterile distilled water (SDW). The suspension was filtered through glass wool and the concentration of conidia was adjusted to $10^{5} / \mathrm{mL}$ using SDW.

\section{Inoculation of fruits}

Two sets of fruits, each set containing 8 fruits from each treatment as per Table 1 was used for each inoculation. One set of fruits was inoculated with the fungus while the other set was kept as a control. Two drops $(20 \mu \mathrm{L})$ of conidia from the conidial suspension prepared as stated before were placed on the surface of each fruit to inoculate the fruit with $C$. gloeosporioides. The control fruits were treated with 2 drops $(20 \mu \mathrm{L})$ of SDW. All fruits were maintained in moist chambers $(95-100 \% \mathrm{RH})$ at $28 \pm$ $2{ }^{\circ} \mathrm{C}$. When the lesions developed to a measurable size, diameters of the lesions were measured along the 2 axis at right angles to each other. Measurements were taken daily for 5 days. The average lesion area was calculated for each fruit and subsequently for each cultivar.

\section{Appressoria formation by $C$. gloeosporioides}

Thin peel sections were removed from the inoculated spots of the treated fruits and the control fruits separately at 24, 48 and $72 \mathrm{~h}$ after inoculation. These sections were observed under high power of a light microscope (Model MOTIC SFC-100 series, China) and the percentage number of appressoria formed (number of spores with appressoria/ total number of spores $\times 100$ ) in 10 fields of vision were counted.

\section{Statistical analysis}

Data relevent to each parameter were subjected to ANOVA and the means were compared by Duncan Multiple Range Test using statistical package of SAS.

\section{RESULTS}

Effect of different doses of potassium and silicon on physical and physicochemical parameters

\section{Maheshi}

Tomato cultivar 'Maheshi' harvested from crops treated with $\times 2$ and $\times 3$ the recommended dosage of $\mathrm{K}$ showed higher average weights of $65.30 \mathrm{~g}$ and $64.54 \mathrm{~g}$, 
respectively compared to the control fruits $(48.15 \mathrm{~g})$ (Table 2).

The diameter of fruits treated with $\times 3$ and $\times 2$ the recommended dosage of $\mathrm{K}$ was significantly larger $(17 \mathrm{~cm})$ compared to that of the controls $(15 \mathrm{~cm})$. However, there was no significant difference in fruit firmness, TSS or $\%$ TA among the fruits harvested from the treated plants.

Weight of the fruits harvested from tomato plants treated with either 50 or $100 \mathrm{mg} / \mathrm{L} \mathrm{Si} \mathrm{showed} \mathrm{no} \mathrm{significant}$ difference compared to the controls. However, the highest weight was observed in fruits from plants treated with $50 \mathrm{mg} / \mathrm{L} \mathrm{Si}$ at the flowering stage. Size of the fruits from plants treated with 50 or $100 \mathrm{mg} / \mathrm{L} \mathrm{Si}$ at the growth or flowering stage or at both stages were significantly larger compared to controls. The largest diameter was observed in fruits from plants treated with $50 \mathrm{mg} / \mathrm{L} \mathrm{Si}$ applied at flowering stage. The fruits from plants treated with 50 or $100 \mathrm{mg} / \mathrm{L}$ of $\mathrm{Si}$ at both stages showed a higher firmness of 8.8 and 8.3 , respectively when compared with the fruits from plants treated with the same dose of Si but applied at only one growth stage.

Fruits from plants treated with either 50 or $100 \mathrm{mg} / \mathrm{L}$ Si showed significantly lesser TSS and \% TA compared to untreated controls. The lowest TSS $\left(2.43^{\circ}\right.$ Brix $)$ was observed in fruits from plants treated with $100 \mathrm{mg} / \mathrm{L}$ of $\mathrm{Si}$ at flowering stage and the highest TSS (3.32 ${ }^{\circ}$ Brix $)$ was observed in fruits from plants treated with $50 \mathrm{mg} / \mathrm{L}$ of $\mathrm{Si}$ at both stages.

\section{Thilina}

No significant change in fruit weight was observed in 'Thilina' plants treated with $\mathrm{K}$ either at $\times 2$ or $\times 3$ the recommended dosage compared with the control. A significantly higher fruit size was observed in plants treated with either twice or thrice the recommended dose of $\mathrm{K}$, compared with the controls. The highest fruit size $(14.4 \mathrm{~cm})$ was recorded from plants treated with $\times 3 \mathrm{~K}$ level (Table 3). The firmness of fruits treated with extra doses of $\mathrm{K}$ was not significantly $(\mathrm{p} \leq 0.05)$ different compared with the control. TSS was significantly higher in fruits from plants treated with higher doses of K. However, the acidity was significantly lower in plants treated with $\times 3$ the recommended $\mathrm{K}$ dose.

The weights and the sizes were higher in the fruits from plants treated with 50 or $100 \mathrm{mg} / \mathrm{L}$ Si applied at either growth stage or flowering stage or both stages (Table 3 ). However, a significant difference was observed only in fruits from plants treated with $50 \mathrm{mg} / \mathrm{L} \mathrm{Si}$ at growth or

Table 2: Some physical and physicochemical parameters of tomato cultivar 'Maheshi' grown under different concentrations of potassium or silicon at different growth stages

\begin{tabular}{|c|c|c|c|c|c|}
\hline Treatment & Weight (g) & Size $(\mathbf{c m})$ & Firmness (N) & TSS ( ${ }^{0}$ Brix) & Acidity \\
\hline $2.6 \mathrm{~g}$ potassium (Control) & $48.15^{a b}$ & $15.10^{\text {a }}$ & $7.2^{\text {a }}$ & $4.08^{\mathrm{d}}$ & $0.78^{\mathrm{e}}$ \\
\hline $5.2 \mathrm{~g}$ potassium $(\mathrm{x} 2 \mathrm{~K})$ & $65.30^{\mathrm{b}}$ & $16.97^{\mathrm{b}}$ & $7.36^{\mathrm{a}}$ & $2.76^{\mathrm{ab}}$ & $0.53^{\mathrm{ab}}$ \\
\hline $7.8 \mathrm{~g}$ potassium $(\mathrm{x} 3 \mathrm{~K})$ & $64.54^{\mathrm{b}}$ & $17.08^{b}$ & $7.45^{a}$ & $3.02 \mathrm{bc}$ & $0.50^{\mathrm{a}}$ \\
\hline $50 \mathrm{mg} / \mathrm{L}$ silicon, growth & $64.71^{\mathrm{b}}$ & $16.17^{\mathrm{b}}$ & $7.38^{\mathrm{bc}}$ & $2.72^{a b}$ & $0.59^{\mathrm{d}}$ \\
\hline $50 \mathrm{mg} / \mathrm{L}$ silicon, flowering & $66.76^{\mathrm{b}}$ & $16.93^{b}$ & $7.26^{\mathrm{a}}$ & $2.52^{\mathrm{a}}$ & $0.57 \mathrm{~cd}$ \\
\hline $50 \mathrm{mg} / \mathrm{L}$ silicon, both stages & $66.32^{\text {a }}$ & $16.44^{b}$ & $8.80^{\mathrm{c}}$ & $3.32^{\mathrm{c}}$ & $0.55^{b c}$ \\
\hline $100 \mathrm{mg} / \mathrm{L}$ silicon, growth & $54.32^{\mathrm{ab}}$ & $16.01^{b}$ & $7.62^{a b}$ & $2.52^{\mathrm{a}}$ & $0.54 \mathrm{bc}$ \\
\hline $100 \mathrm{mg} / \mathrm{L}$ silicon, flowering & $54.10^{\mathrm{ab}}$ & $15.90^{\mathrm{b}}$ & $7.40^{a b}$ & $2.43^{\mathrm{a}}$ & $0.53 \mathrm{bc}$ \\
\hline $100 \mathrm{mg} / \mathrm{L}$ silicon, both stages & $54.06^{\mathrm{ab}}$ & $15.98^{b}$ & $8.30^{\mathrm{bc}}$ & $3.04 \mathrm{bc}$ & $0.56^{\mathrm{bc}}$ \\
\hline
\end{tabular}

Mean values $(\mathrm{n}=12)$ followed by the same superscript in each column did not differ significantly at $\mathrm{p} \leq 0.05$ by the Duncan Multiple Range Test

flowering stages or with $100 \mathrm{mg} / \mathrm{L} \mathrm{Si}$ at flowering stage. The fruits treated with $100 \mathrm{mg} / \mathrm{L}$ Si at both stages showed significantly higher degree of firmness compared to the controls. Significantly lower TSS was observed in fruits from plants treated with $100 \mathrm{mg} / \mathrm{L}$ Si. Fruit acidity was significantly lower when plants were treated with 50 or $100 \mathrm{mg} / \mathrm{L} \mathrm{Si}$ irrespective of the stage of plant at which Si was applied.

\section{Assessment of postharvest disease resistance}

\section{Effect of potassium on anthracnose lesion development}

A significant reduction in lesion diameter was observed in fruits from plants treated with extra doses of K compared with the control. A reduction of 85 or $86 \%$ of lesion 
Table 3: Some physical, physico chemical parameters of tomato cultivar 'Thilina' grown under different concentrations of potassium and silicon at different growth stages

\begin{tabular}{lccccc}
\hline Treatments & Weight (g) & Size (cm) & Firmness (N) & TSS ( ${ }^{\circ}$ Brix) & Acidity (\% TA) \\
\hline 2.6 g potassium (control) & $40.79^{\mathrm{a}}$ & $13.04^{\mathrm{a}}$ & $8.68^{\mathrm{abc}}$ & $3.24^{\mathrm{c}}$ & $0.60^{\mathrm{b}}$ \\
$5.2 \mathrm{~g}$ potassium & $50.91^{\mathrm{abc}}$ & $14.2^{\mathrm{ab}}$ & $9.55^{\mathrm{bcd}}$ & $3.48^{\mathrm{d}}$ & $0.63^{\mathrm{b}}$ \\
$7.8 \mathrm{~g}$ potassium & $51.2^{\mathrm{abc}}$ & $14.4^{\mathrm{ab}}$ & $8.025^{\mathrm{a}}$ & $3.4^{\mathrm{d}}$ & $0.53^{\mathrm{a}}$ \\
$50 \mathrm{mg} / \mathrm{L}$ silicon, growth & $59.68^{\mathrm{c}}$ & $14.7^{\mathrm{b}}$ & $9.55^{\mathrm{bcd}}$ & $3.40^{\mathrm{d}}$ & $0.64^{\mathrm{b}}$ \\
$50 \mathrm{mg} / \mathrm{L}$ silicon, flowering & $55.63^{\mathrm{b}}$ & $14.32^{\mathrm{b}}$ & $8.49^{\mathrm{ab}}$ & $3.32^{\mathrm{c}}$ & $0.61^{\mathrm{b}}$ \\
$50 \mathrm{mg} / \mathrm{L}$ silicon, both stages & $45.80^{\mathrm{ab}}$ & $14.07^{\mathrm{a}}$ & $9.73^{\mathrm{cd}}$ & $3.36^{\mathrm{d}}$ & $0.60^{\mathrm{b}}$ \\
$100 \mathrm{mg} / \mathrm{L}$ silicon, growth & $52.94 \mathrm{a}$ bcd & $14.14^{\mathrm{ab}}$ & $8.35^{\mathrm{a}}$ & $2.68^{\mathrm{a}}$ & $0.60^{\mathrm{b}}$ \\
$100 \mathrm{mg} / \mathrm{L}$ silicon, flowering & $75.50^{\mathrm{e}}$ & $15.66^{\mathrm{cd}}$ & $10.5^{\mathrm{d}}$ & $2.90^{\mathrm{ab}}$ & $0.55^{\mathrm{a}}$ \\
$100 \mathrm{mg} / \mathrm{L}$ silicon, both stages & $51.51^{\mathrm{abc}}$ & $13.91^{\mathrm{ab}}$ & $10.07^{\mathrm{d}}$ & $3.04^{\mathrm{bc}}$ & $0.55^{\mathrm{a}}$ \\
\hline
\end{tabular}

Mean values $(\mathrm{n}=12)$ followed by the same superscript in each column did not differ significantly at $\mathrm{p} \leq 0.05$ by the Duncan Multiple Range Test

diameter was observed in fruits from plants treated with thrice the recommended $\mathrm{K}$ dose in both 'Maheshi' and 'Thilina'. However, the reduction was only $30 \%$ in the fruits from plants treated with twice the recommended $\mathrm{K}$ level.

\section{Effect of silicon on anthracnose lesion development}

Fruits from plants treated with silicon showed a significantly lower lesion diameter (over $80 \%$ reduction) compared to untreated controls in both cultivars. The lowest lesion diameters ( 87 or $89 \%$ reduction compared to the control fruits) were observed in fruits from plants treated with $100 \mathrm{mg} / \mathrm{L} \mathrm{Si}$ in 'Maheshi' and 'Thilina' irrespective of the stage of growth at which the treatment was applied. In both cultivars, an additional $5 \%$ reduction in disease symptoms was observed in plants treated with $100 \mathrm{mg} / \mathrm{L} \mathrm{Si}$ when compared to $50 \mathrm{mg} / \mathrm{L} \mathrm{Si}$. However, there was no significant difference.

A significantly higher percentage number of appressoria was present on the fruit peels from plants treated with $\mathrm{Si}$ and with three times the K dose compared to the controls. The highest percentage number of appressoria was observed 72 hours after inoculation in the fruits from plants treated with 100 or $50 \mathrm{mg} / \mathrm{L}$ $\mathrm{Si}$ applied at any of the two growth stages. The lowest number of appressoria was observed in the controls.

\section{DISCUSSION}

This study was conducted to investigate the effect of $\mathrm{K}$ and $\mathrm{Si}$ to improve disease resistance against anthracnose and the quality of tomato fruit of the cultivars, 'Thilina' and 'Maheshi'.
It was revealed that in 'Maheshi', the size of the fruit was significantly higher in plants treated with thrice the recommended dose of $\mathrm{K}$. It has been reported that the fruit weight of apple (Attala, 1998) and guava (Psidium guajava) (Ke \& Wang, 1997) increased with soil application of K. It is also reported that the size, colour, firmness and sugar of the fruit increased in $\mathrm{K}$ treated banana (Wojcik, 2005) and apple (Nava et al., 2009). In the present study there was no significant effect on firmness, TSS and TA \% observed in K treated 'Maheshi'. However, TSS and acidity were significantly higher in fruits from plants treated with thrice the recommended amounts of $\mathrm{K}$.

Higher amounts of $\mathrm{K}$ enhanced the disease resistance in both 'Maheshi' and 'Thilina'. It has been reported that application of $\mathrm{K}$ salts with nitrogen enhanced the resistance to Alternaria solani in tomato by inhibiting spore germination and mycelial growth (Blachinski et al., 1996). Potassium phosphate has been identified as the active component in early papilla formation and resistance of barley to powdery mildew (Inoue et al., 1994). In the present study, resistance against anthracnose in fruits from $\mathrm{K}$ treated tomato plants might be due to the physical hindrance created to the fungal pathogen against disease invasion.

The present study reveals that the application of $\mathrm{Si}$ results in significantly higher weight and size of fruits in 'Maheshi'. The sizes and weights of fruits did not significantly increase in any of the treatments in 'Thilina'. The Si treatment had a negative effect on the TSS of fruit. Fruit TSS were significantly lower in Si treated crops of both tomato cultivars. However, Stamatakis et al. (2003) have reported that pre harvest application of $\mathrm{Si}$ on tomato 
increased the contents of $\beta$-carotene, lycopene, TSS and vitamin $\mathrm{C}$ contents in fruits.

The plants treated with silicon $(100 \mathrm{mg} / \mathrm{L})$ applied at both stages showed fruits with higher firmness in both tomato cultivars.

In the present study, silicon (100 mg/L) applied at any stage of the crop resulted in optimum disease reduction $(87-89 \%)$. Therefore, applying $\mathrm{Si}$ at any one stage (flowering /growth) would be sufficient for controlling the disease. Similarly, the severity of anthracnose disease in flowering chinese cabbage (Yang et al., 2008), bean (Polanco et al., 2012) and avocado (Anderson et al., 2005) were reduced by application of soluble silicon.

The current study revealed that the percentage number of appressoria formed by $C$. gloeosporioides in the inoculated sites of tomato fruit surfaces were higher in fruits from silicon treated plants compared to controls. In the pre infection stages of anthracnose, conidia adhere to and germinate on the plant surface, producing germ tubes that form appressoria, which penetrate the cuticle directly and spread rapidly throughout the tissues. Following penetration, the pathogens that colonize the intramural region beneath the cuticle invade in a necrotrophic manner and spread rapidly throughout the tissues. It is recorded that if the penetration process is hindered, the appressorial count remains higher on the surface of the tissue (Bailey et al., 1992). In this study, the high appressorial number implies the presence of a physical barrier over the surface of fruit peel from silicon treated plants, which would obstruct the infection process of $C$. gloeosporioides. This may be the reason that the fruit having lesser disease symptoms had a higher number of appressoria in the epidermal peel.

It has been recorded that application of liquid potassium silicate suppressed conidial germination and appressorial formation of Sphaerotheca aphanis var. aphanis, which causes powdery mildew on strawberry (Kanto et al., 2006). Disease severity of Fusarium oxysporum f.sp. radicis-lycopersici (FCRR), the causal agent of fusarium crown and root rot was reduced as a result of silicon application to tomato seedlings. This was caused by delaying the onset and initial infection of roots and the movement of the pathogen from roots to stems (Huang et al., 2011).

Formation of a physical barrier has been proposed to explain Si-mediated resistance (Datnoff et al., 2007). $\mathrm{Si}$ can accumulate and deposit beneath the cuticle to form a cuticle-Si double layer, preventing penetration of pathogens in leaves (Datnoff et al., 2007).

The present study reveals that soil application of silicon or application of three times the recommended dosage of K significantly controls the anthracnose disease in tomato cultivars 'Thilina' and 'Maheshi'. Although the application of higher doses of $\mathrm{K}$ was beneficial it is recommended that the level of $\mathrm{K}$ in the soil should be analysed prior to application to avoid possible adverse effects to the plants.

Table 4: Development of anthracnose lesions in tomato fruit inoculated with C. gloeosporioides

\begin{tabular}{|c|c|c|}
\hline \multirow[t]{2}{*}{ Treatment } & \multicolumn{2}{|c|}{ Mean value of the lesion diameter $(\mathrm{cm})$} \\
\hline & Maheshi & Thilina \\
\hline $2.6 \mathrm{~g}$ potassium (control) & $1.79^{\mathrm{c}}$ & $1.92^{\mathrm{c}}$ \\
\hline $5.2 \mathrm{~g}$ potassium & $1.25^{\mathrm{b}}(30 \%)^{\#}$ & $1.24^{\mathrm{b}}(35 \%)$ \\
\hline $7.8 \mathrm{~g}$ potassium & $0.27^{\mathrm{a}}(85 \%)$ & 0.27 a $(86 \%)$ \\
\hline $50 \mathrm{mg} / \mathrm{L}$ silicon, growth & $0.35^{\mathrm{a}}(80 \%)$ & $0.30^{\mathrm{a}}(84 \%)$ \\
\hline $50 \mathrm{mg} / \mathrm{L}$ silicon, flowering & $0.27^{\mathrm{a}}(85 \%)$ & $0.33^{\mathrm{a}}(83 \%)$ \\
\hline $50 \mathrm{mg} / \mathrm{L}$ silicon, both stages & $0.28^{a}(84 \%)$ & $0.28^{\mathrm{a}}(85 \%)$ \\
\hline $100 \mathrm{mg} / \mathrm{L}$ silicon, growth & $0.23^{\mathrm{a}}(87 \%)$ & $0.22^{\mathrm{a}}(87 \%)$ \\
\hline $100 \mathrm{mg} / \mathrm{L}$ silicon, flowering & $0.23^{\mathrm{a}}(87 \%)$ & $0.24^{\mathrm{a}}(88 \%)$ \\
\hline $100 \mathrm{mg} / \mathrm{L}$ silicon, both stages & $0.23^{\mathrm{a}}(87 \%)$ & $0.24^{\mathrm{a}}(88 \%)$ \\
\hline
\end{tabular}

Mean values $(\mathrm{n}=12)$ followed by the same superscript in each column did not differ significantly at $\mathrm{p} \leq 0.05$ by the Duncan Multiple Range Test

\#Values in parentheses represent percentage reduction of disease 
Table 5: Percentage of appressoria formed by C. gloeosporioides on the surface of fruit 'Thilina' treated with potassium and silicon

\begin{tabular}{|c|c|c|c|}
\hline \multirow[t]{2}{*}{ Treatments } & \multicolumn{3}{|c|}{ Number of appressoria present on a microscopic field (\%) } \\
\hline & $24 \mathrm{~h}$ & $48 \mathrm{~h}$ & $72 \mathrm{~h}$ \\
\hline $2.6 \mathrm{~g}$ of potassium-control & $17^{\mathrm{a}}$ & $24^{\text {a }}$ & $29^{\text {a }}$ \\
\hline $5.2 \mathrm{~g}$ of potassium. & $19^{\mathrm{a}}$ & 28 ab & $31^{\text {a }}$ \\
\hline $7.8 \mathrm{~g}$ of potassium & $34^{\mathrm{b}}$ & $44^{\mathrm{cd}}$ & $45^{\mathrm{bc}}$ \\
\hline $50 \mathrm{mg} / \mathrm{L}$ silicon, growth & $36^{\mathrm{b}}$ & $52^{\mathrm{d}}$ & $58^{\mathrm{c}}$ \\
\hline $50 \mathrm{mg} / \mathrm{L}$ silicon, flowering & $29^{b}$ & $36^{\mathrm{bc}}$ & 34 ab \\
\hline $50 \mathrm{mg} / \mathrm{L}$ silicon, both stages & $61^{\mathrm{d}}$ & $89^{\mathrm{f}}$ & $94^{\mathrm{e}}$ \\
\hline $100 \mathrm{mg} / \mathrm{L}$ silicon, growth & $32^{b}$ & $41^{\mathrm{c}}$ & $46^{\mathrm{bc}}$ \\
\hline $100 \mathrm{mg} / \mathrm{L}$ silicon, flowering & $47^{\mathrm{c}}$ & $72^{\mathrm{e}}$ & $76^{\mathrm{d}}$ \\
\hline $100 \mathrm{mg} / \mathrm{L}$ silicon, both stages & $82^{\mathrm{e}}$ & $92^{\mathrm{f}}$ & $94^{\mathrm{e}}$ \\
\hline
\end{tabular}

Mean values $(n=12)$ followed by the same superscript in each column did not differ significantly at $\mathrm{p} \leq 0.05$ by the Duncan Multiple Range Test

\section{REFERENCES}

1. Anderson J.M., Pegg K.G., Dann E.K., Cooke A.W., Smith L.A., Willingham S.L., Giblin F.R., Dean J.R. \& Coates L.M. (2005). New strategies for the integrated control of avocado fruit diseases. New Zealand and Australia Avocado Grower's Conference, 20 - 22 September, Tauranga, New Zealand, pp. $1-6$.

2. Askar A.A. \& Trepow H. (1993). Quality Assurance in Tropical Fruit Processing, pp. 9 - 25, Springer Verlag, New York, USA. DOI: http://dx.doi.org/10.1007/978-3-642-77687-8

3. Attala E.S. (1998). Effect of potassium fertilization on Anna apple trees grown in sandy soils of Egypt. Egyptian Journal of Agricultural Research 7: 709 -719.

4. Bailey J.A., O'Connell R.J., Spring R.J. \& Nash C. (1992). Infection strategies of Colletotrichum species. Colletotrichum: Biology, Pathology, and Control (eds. J.A. Bailey \& M.J. Jeger), pp 88 - 120. CAB International, Wallingford, UK.

5. Blachinski D., Shtienberg D., Dinoor A., Kafkafi U., Sujkowski L.S., Zitter T. A. \& Fry W.E. (1996). Influence of foliar application of nitrogen and potassium on Alternaria diseases in potato, tomato and cotton. Phytoparasitica 24(4): $281-292$.

DOI: http://dx.doi.org/10.1007/BF02981411

6. Datnoff L.E., Rodrigues F.Á. \& Seebold K.W. (2007). Silicon and plant disease. Mineral Nutrition and Plant Disease (eds. L.E. Datnoff, W.H. Elmer \& D.M. Huber), pp. 233 - 246. APS Press, St. Paul, USA.

7. Department of Agriculture (2011). Tomato Cultivation, p. 1. Department of Agriculture, Gannoruwa, Peradeniya.

8. Huang Cheng-Hua, Roberts P.D. \& Datnoff L.E. (2011). Silicon suppresses Fusarium crown and root rot of tomato. Journal of Phytopathology 119: 546 - 554.
DOI: http://dx.doi.org/10.1111/j.1439-0434.2011.01803.x

9. Inoue S., Macko V. \& Aist J.R. (1994). Identification of the active component in the papilla-regulating extract from barley leaves. Physiological Molecular Plant Pathology 44: $441-453$.

10. Kanai S., Ohkura K., Adu- gyamfi J.J., Mohapatra P.K., Nguyen N.T., Saneoka H. \& Fujita K. (2007). Depression of sink activity precedes the inhibition of biomass production in tomato plants subjected to potassium deficiency stress. Journal of Experimental Botany 58: 2917 - 2928. DOI: http://dx.doi.org/10.1093/jxb/erm149

11. Kanto T., Miyoshi A., Ogawa T., Maekawa K. \& Aino M. (2006). Suppressive effect of liquid potassium silicate on powdery mildew of strawberry in soil. Journal of General Plant Pathology 72(3): 137 - 142.

DOI: http://dx.doi.org/10.1007/s10327-005-0270-8

12. Karunanayake K.O.L.C. (2008). Natural defence mechanisms in mango fruit and their potential in management of postharvest diseases, Ph.D thesis, University of Peradeniya, Sri Lanka.

13. Ke L.S. \& Wang W.D. (1997). Effects of nitrogen, phosperous and potassium fertilizer levels on yield and quality of guava (Psidium guajava L.). Journal of Agricultural Association China 179: 15 - 19.

14. Koo R.C.J. (1985). Potassium nutrition of citrus. Potassium in Agriculture (ed. R.S. Munson), pp. 1077 - 1086. ASACSSA- SSSA, Madison, USA.

15. Menzies J., Bowen P., Ehret D. \& Glass A.D.M. (1992). Foliar applications of potassium silicate reduce severity of powdery mildew on cucumber, muskmelon, and zucchini squash. Journal of the American Society for Horticultural Science 117: $902-905$.

16. Nava G., Roque- Dechen A. \& Riberro- Nachtia G. (2008). Nitrogen and potassium fertilization affect apple fruit quality in Southern Brazil. Communications in Soil Science 
and Plant Analysis 39: $96-107$.

DOI: http://dx.doi.org/10.1080/00103620701759038

17. Palmer S., Scott E., Stangoulis J. \& Able A. (2006). The effects of foliar-applied $\mathrm{Ca}$ and $\mathrm{Si}$ on the severity of powdery mildew in two strawberry cultivars. Acta Horticulturae 708: $135-139$.

18. Rodrigues F.A. \& Datnoff L.E. (2005). Silicon and rice disease management. Fitopatologia Brasileira 30(5): $457-469$.

DOI: http://dx.doi.org/10.1590/S0100-41582005000500001

19. Polanco L.R., Rodrigues F.A., Nascimento K.J.T., Shulman P., Silva L.C., Neves F.W. \& Vale F.X.R. (2012). Biochemical aspects of bean resistance to anthracnose mediated by silicon. Annals of Applied Biology 161(2): $140-150$.

DOI: http://dx.doi.org/10.1111/j.1744-7348.2012.00558.x
20. Stamatakis A., Papadantonakis N., Savvas D., Lydakis - simantiris N. \& Kefalas P. (2003). Effects of silicon and salinity on fruit yield and quality of tomato grown hydroponically. ISHS Acta Horticulture 609: 141 - 147. Abstract Only.

21. Weerakoon W.R.W.M.A.U., Abayasekara C.L. \& Adikaram N.K.B. (2005). The Effect of soil potassium on postharvest fungal diseases of banana. Proceedings and Abstracts Peradeniya University Research Sessions 10: 94.

22. Wojcik P. (2005). Effect of foliar potassium on the yield and quality of tomato. Xinjiang Agriculture Science 42: $272-275$.

23. Yang X., Feng H.X. \& Yang Y. (2008). Effects of silicon on flowering Chinese cabbage's anthracnose occurrence, flower stalk formation, and silicon uptake and accumulation. The Journal of Applied Ecology 19(5): 1006. 